\title{
Temporal trends of mercury concentrations in Wisconsin walleye (Sander vitreus), 1982-2005
}

\author{
Paul W. Rasmussen · Candy S. Schrank • \\ Patrick A. Campfield
}

Accepted: 26 June 2007/Published online: 27 July 2007

(C) Springer Science+Business Media, LLC 2007

\begin{abstract}
The Wisconsin Department of Natural Resources has monitored mercury $(\mathrm{Hg})$ in several species of fish since the early 1970s primarily for fish consumption advisory purposes. We selected skin-on fillets of walleye (Sander vitreus) from inland lakes collected over the years 1982-2005 to assess temporal trends of $\mathrm{Hg}$ concentrations. While individual lakes are of interest, sample sizes, and unbalanced collections across fish lengths, seasons, or years prevent estimates of temporal trends of walleye $\mathrm{Hg}$ concentrations within most lakes. We evaluated temporal trends over all lakes using mixed effects models $(3,024$ records from 421 lakes). Relationships between $\mathrm{Hg}$ concentrations and a suite of lake chemistry, morphometry, and other variables were also explored. $\mathrm{Hg}$ concentrations generally increased with walleye length but the relationship varied among lakes. The best-fitting mixed effects models suggested that the overall rate of change in walleye $\mathrm{Hg}$ across all lakes in the dataset varied with latitude. $\mathrm{Hg}$ in walleye decreased $0.5 \%$ per year in northern lakes, increased $0.8 \%$ in southern lakes, and remained constant in middle latitude lakes over the period of 1982-2005. Season of collection was also an important predictor variable. $\mathrm{Hg}$ concentrations were highest in walleye captured in the spring and lowest in the fall. Other variables such as gender, lake area, and total alkalinity were also important predictors.
\end{abstract}

\footnotetext{
P. W. Rasmussen

Wisconsin Department of Natural Resources, Science Services, 2801 Progress Road, Madison, WI 53716-3339, USA

C. S. Schrank $(\bowtie)$ · P. A. Campfield

Wisconsin Department of Natural Resources,

Fisheries Management, 101 S. Webster St., Madison,

WI 53705-7921, USA

e-mail: Candy.Schrank@wisconsin.gov
}

Keywords Mercury - Walleye - Temporal trends · Wisconsin $\cdot$ Bioaccumulation

\section{Introduction}

Mercury $(\mathrm{Hg})$ concentrations in a variety of ecosystems have increased in the range of two to tenfold over preindustrial levels. Widespread Hg contamination and accumulation in fish poses health risks to people who consume fish and may impair wildlife health. Scientists have concluded that fish $\mathrm{Hg}$ concentrations will respond to changes in $\mathrm{Hg}$ loading rates. However, few reports demonstrate fish responses to control of $\mathrm{Hg}$ emissions and $\mathrm{Hg}$ inputs to surface waters from atmospheric loading. In addition, the magnitude and timing of the response of fish $\mathrm{Hg}$ to changes in atmospheric loading will vary due to a variety of factors influencing individual ecosystems (Munthe et al. 2007).

Most of the $\mathrm{Hg}$ that accumulates in fish is from anthropogenic sources and enters water via atmospheric deposition, accounting for most of the $\mathrm{Hg}$ in fish that inhabit remote lakes far from any point source (Glass and Sorensen 1999; Wiener et al. 2006). Sediment cores from lakes in Minnesota's Voyageurs National Park suggest Hg deposition rates increased after the mid-1800s with most $\mathrm{Hg}$ originating from anthropogenic sources (Wiener et al. 2006). Schuster et al. (2002) examined ice cores from the Fremont glacier in western Wyoming USA and found that $\mathrm{Hg}$ deposition increased during the industrial era, then decreased since the late 1980s possibly reflecting regulatory limitations on select sources of $\mathrm{Hg}$ to the environment. Estimated worldwide atmospheric $\mathrm{Hg}$ levels peaked in the late 1980s, decreased from the 1980s to 1996, and have varied little since 1996 (Slemr et al. 2003). 
Few studies have examined temporal trends in fish $\mathrm{Hg}$ from $\mathrm{Hg}$-sensitive waters like the lakes typical of northern Wisconsin. Suns and Hitchin (1990) examined yearling yellow perch from 16 Canadian lakes and found no temporal trends in $\mathrm{Hg}$ concentrations over a 9-year period (1978-1987). The authors concluded that $\mathrm{Hg}$ inputs and conversion to bioavailable forms were also constant during this time. Hrabik and Watras (2002) found decreases in $\mathrm{Hg}$ deposition and $\mathrm{Hg}$ water column concentrations in one northern Wisconsin lake from 1994 to 2000. Hg concentrations in adult yellow perch from this lake also declined by $5 \%$ per year suggesting that $\mathrm{Hg}$ concentrations in adult fish decrease in response to reductions in $\mathrm{Hg}$ deposition. However, $\mathrm{Hg}$ trends in fish may not directly reflect changes in $\mathrm{Hg}$ emissions. Fish are exposed over a number of years and factors that affect bioaccumulation may vary spatially and temporally (Wiener et al. 2007).

Fish $\mathrm{Hg}$ concentrations increase with fish length, although the relationship varies among lakes (Lathrop et al. 1991; Somers and Jackson 1993). Some differences in $\mathrm{Hg}$ accumulation among lakes may be due to differences in fish growth rates (Simoneau et al. 2005). Studies have established the importance of lake morphometry and watershed characteristics in determining fish $\mathrm{Hg}$ levels (Bodaly et al. 1993; Rudd 1995; St. Louis et al. 1996). Lake chemistry, especially $\mathrm{pH}$, alkalinity, and dissolved organic carbon, also affect $\mathrm{Hg}$ levels in fish (Wiener et al. 1990; Driscoll et al. 1995; Watras et al. 1998).

The Wisconsin Department of Natural Resources (WIDNR) has monitored $\mathrm{Hg}$ in fish since the early $1970 \mathrm{~s}$ with the main purpose of determining appropriate advice for human consumption of fish. Monitoring designs evolved over time as more was learned about environmental contaminants and risks to human health from consumption of contaminated fish. Monitoring began in the 1970s to evaluate $\mathrm{Hg}$ concentration in fish from rivers receiving treated wastewater from facilities that used $\mathrm{Hg}$ based slimicides. In the 1980s, atmospheric deposition, methylation and bioaccumulation of $\mathrm{Hg}$ in the food chain became a concern. When Wiener (1983) reported elevated $\mathrm{Hg}$ concentrations in sport fish from northern Wisconsin, the focus of monitoring shifted to lakes in that area. As a result, statewide $\mathrm{Hg}$ monitoring in Wisconsin fish was generally not conducted under a single study design that controlled spatial and temporal sampling patterns. Sampling for fish consumption advisories focuses on popular fishing lakes. However, the data also include fish collected for other purposes, including special studies of individual lakes, and general sport fish surveys. Each sample is affected by many uncontrolled factors, including lake characteristics such as water chemistry, underlying geology, watershed position, local climate, and local landscape cover, as well as temporal and spatial patterns of sampling.
Because of the large number of fish sampled and the 29year time span, these data provide a valuable resource for examining spatial and temporal patterns of $\mathrm{Hg}$ contamination in Wisconsin fish.

Our objectives were to evaluate temporal trends while accounting for factors not controlled or randomized during sampling. We also wanted to characterize Wisconsin's walleye $\mathrm{Hg}$ concentrations in relation to fish length and lake attributes that have been shown to be important to $\mathrm{Hg}$ accumulation including lake morphometry, watershed, chemistry characteristics.

\section{Methods}

\section{Description of datasets}

Wisconsin Department of Natural Resource's fish contaminant database contains $\mathrm{Hg}$ results for 4,961 skin-on fillets from walleye collected over the years 1977-2005 from 607 locations. Following the recommendations of Wiener et al. (2007), we selected walleye skin-on fillets for our analysis because they are an important game fish highly sought by anglers, represent the largest number of observations in Wisconsin's fish contaminant database, and are a top-level piscivorous species that accumulate high concentrations of $\mathrm{Hg}$. A dataset was selected for trend analysis by removing records from riverine-dominated flowages which may obscure responses to changes in atmospheric Hg loading (Wiener et al. 2007). WIDNR staff collected most walleye samples using typical fisheries survey methods, including electrofishing and netting (Fisheries Management Handbook 3605.9, Contaminant Fish Collection Procedures, and the WIDNR Field Procedures Manual Version IV). After collection and labeling, samples were frozen and later transported to a processing facility where they were measured, weighed, and filleted. Gender was determined for most mature individuals by gross examination of the gonads. Fish age was estimated for a subset of samples using scales and spines. Skin-on fillets were homogenized and subsamples placed in glass jars. Samples were analyzed for total $\mathrm{Hg}$ content according to the methods described in Sullivan and Delfino (1982). Total $\mathrm{Hg}$ in fish is comprised almost entirely of methylmercury (Weiner et al. 2007). Results were reported to two significant digits and the level of detection was $0.03 \mu \mathrm{g} / \mathrm{g}$ for samples analyzed prior to June 1994 and $0.004 \mu \mathrm{g} / \mathrm{g}$ after that date.

We compiled data on lake morphometry, hydrology, and water chemistry variables previously shown to affect $\mathrm{Hg}$ accumulation in fish from WIDNR databases for the lakes included in the walleye $\mathrm{Hg}$ trend dataset $(n=421)$. Water chemistry values were measured using conventional 
laboratory procedures (Wisconsin State Laboratory of Hygiene 2005). We calculated lake-specific water chemistry values for statistical comparisons and modeling as the geometric mean of values from multiple years for each season, and then calculated a grand mean for each individual lake. Only results from surface samples were included in the calculations in order to standardize the data.

\section{Statistical analyses}

All statistical analyses were performed using SAS Version 9.1 (SAS Institute, Cary, NC, USA). We used log-transformed $\mathrm{Hg}$ concentrations $\left(\log _{10} \mathrm{Hg}\right)$ as the response variable for analyses because the variance of residuals was more homogeneous on this scale. We converted year of collection to a value equal to the number of years since 1980. For example, a collection year of 1992 was given a value of 12 (1992-1980). Not all predictor variables were available for all lakes. Therefore, the number of lakes included in the analyses varied by the selected model. We log-transformed waterbody area and adjoining wetland area to linearize the relationship between $\log _{10}(\mathrm{Hg})$ and those predictors. We approximately centered fish length and latitude predictor variables by subtracting overall mean length $(45 \mathrm{~cm})$ and latitude $\left(45^{\circ}\right)$, respectively, from each observation. Centering makes model intercepts more easily interpretable.

We analyzed log-transformed $\mathrm{Hg}$ concentrations using mixed effects models (Littell et al. 1996). Because this was an observational study, with sampling units selected by means outside of our control (Johnson 2002), and with many possible predictor variables, extra care was necessary in selection of predictor variables and specification of a set of candidate models to avoid overfitting and finding of spurious relationships (Burnham and Anderson 1998). Predictor variables were included in our models if we were specifically interested in estimating their effects, if we thought it was essential to adjust for their effects to obtain unbiased estimates of other parameters, or if they were shown to be important to $\mathrm{Hg}$ bioaccumulation. We included lake latitude, season in which each fish was collected, and fish length $(\mathrm{cm})$ in our models to account for possible changes in the spatial distribution of lakes sampled, the seasonal timing of walleye sampling, and the size of walleye targeted for sampling. Lake latitude is also correlated with important gradients in $\mathrm{pH}$ and alkalinity, lake productivity, and fish growth (Colby and Nepszy 1981; Lillie and Mason 1983; Lathrop et al. 1989; Quist et al. 2003; Nate 2004). Fish length is known to be an important determinant of walleye $\mathrm{Hg}$ concentrations and must be accounted for in comparing lakes or estimating trends (Wiener et al. 1990; Lathrop et al. 1991). Water chemistry data were available for only a subset of the lakes sampled for walleye $\mathrm{Hg}$. We included total alkalinity in some of our models because it was available more often than other lake chemistry variables, is strongly correlated with other variables such as lake $\mathrm{pH}$, and has been used in other analyses of Wisconsin walleye $\mathrm{Hg}$ data (Lathrop et al. 1991). We also examined the effects of some lake morphometry and watershed variables, including maximum depth, lake area, adjoining wetland area, and wetland to lake area ratio.

Both individual fish and whole lake predictor variables were included as fixed effects in our models. All models also included random effects to describe the variance of parameters among individual lakes. The random effects allow individual lakes to deviate from the population model determined by the fixed effects. The simplest model of this form allows lakes to deviate from the overall population intercept but not from the single population value for each of the coefficients (i.e., slopes) of the fixed factors. More complicated models for the random effects allow individual lakes to deviate from the population values of the coefficients for one or more of the fixed factors. We included random effects for the intercept, for fish length, and for year when selecting among models with different fixed effects structures (year was included as a random effect only for models in which it was also included as a fixed effect).

We fit models in two stages. We first fit a set of models that allowed us to estimate trends in walleye $\mathrm{Hg}$, while accounting for factors that might bias trend estimates. We included models without year as a factor (i.e., a trend of zero) to provide a direct comparison for the same models with year. We ranked models on the basis of the Akaike Information Criterion (AIC) and examined models within 2 AIC units of the best-fitting model in greater detail, evaluating the random effects structure, and assessing model assumptions. We then fit additional models building on the best model from stage 1 by including factors related to lake morphometry, watershed characteristics, and gender. Model comparisons using AIC were based on maximum likelihood (ML) estimation, while final parameter estimates were obtained using restricted maximum likelihood (REML), as recommended by Verbeke and Molenberghs (2000).

\section{Results}

\section{Data Summary}

Selection of walleye, skin-on fillet records from inland, non-riverine lakes produced a dataset of 3,024 samples collected over the years 1982-2005 from 421 lakes. Individual samples represent a range of walleye size, age, and 
$\mathrm{Hg}$ concentrations (Table 1). The bulk of the samples were collected between 1985 and 1994 (77\% of records) with $2 \%$ from before 1985 , and $21 \%$ from 1995 to 2005 . Records were assigned to a season based on the month of sampling. The majority $(73.7 \%)$ of the samples were collected in the spring (April-June) with $15.6 \%$ collected in summer (July-September) and $10.7 \%$ collected in fall (October-December). Gender was available for a subset of walleye samples $(n=1953)$. Of these $43.7 \%$ were females and $56.3 \%$ were males. The remaining were of uncertain gender either because the fish were not sexually mature or gender was not recorded.

The 421 lakes included in the dataset represent a range of hydrologic, morphometric, and water chemistry conditions (Table 2). The lakes are distributed in 49 of Wisconsin's 72 counties. A majority of the lakes (82\%) are within the 20 most northern counties, approximating the distribution of inland lakes in Wisconsin. Hydrologic conditions include: drainage (58\%) lakes that have both surface water inflow and outflow and stream drainage is the primary water source; seepage $(30 \%)$ lakes that have no surface water inflow or outflow and precipitation or runoff is the primary water source; spring $(8 \%)$ lakes that have no inlet and groundwater is the primary water source; and drained (3\%) lakes that only have a surface water outflow and precipitation or runoff is the primary water source.

We evaluated the characteristics of the walleye records for all 421 lakes in the dataset over all years sampled (Table 3). Lake mean concentrations of $\mathrm{Hg}$ ranged 0.0632.2 and the overall average was $0.483 \mu \mathrm{g} / \mathrm{g}$. Lake mean fish length ranged from 31 to $69 \mathrm{~cm}$. The years and number of years sampled varies by lake and the number of samples per lake ranged 1-36.

Models describing $\mathrm{Hg}$ bioaccumulation and trends

Mercury concentrations increased with walleye length, but the relationship varied among lakes (Fig. 1). Lake differences accounted for $54.7 \%$ of the total variation in walleye $\mathrm{Hg}$ values, while fish length explained $52.9 \%$ of the within lake variation in walleye $\mathrm{Hg}$. Of the models without lake morphometry and watershed variables, the best fitting model included fish length, season, year, latitude, and the latitude by year interaction (Model 1, Table 4).
Including lake mean values for length of fish or year sampled improved the fit of the model slightly ( $\sim$ AIC unit), but did not change parameter estimates for the within-lake effects of length and year (i.e., there was no evidence for bias due to factors such as sampling changes related to fish length or year). This model included random effects for the intercept, fish length, and year; removing any one of these random effects from the model substantially reduced the fit of the model (AIC increased by 100 or more). These random effects allowed individual lakes to deviate from the overall population values for the intercept and for the slopes with respect to fish length and year sampled. The variability introduced by the random effects for the intercept and fish length is illustrated by plotting predicted $\mathrm{Hg}$ for all lakes in a given year (Fig. 2; predictions are for 1995). The variance estimates for the random effects of fish length and year sampled were small (Table 6), but their inclusion greatly improved the fit of the model.

The parameter estimates for the fixed effects model provide the overall population values for these parameters (Table 6). Because of random effects in the model, individual lakes deviated from population values for the intercept and the effects of fish length and year, but not for the effects of season, latitude, and the latitude by year interaction (latitude has only one value for each lake in any case). Although $\mathrm{Hg}$ was log-transformed prior to model fitting, parameter estimates are more interpretable when converted back to the original scale. Linear relationships on the log scale become exponential relationships on the original scale (Fig. 2); thus, the linear increase in $\log _{10}(\mathrm{Hg})$ of 0.0181 per $\mathrm{cm}$ of fish length corresponds to a constant percent increase in $\mathrm{Hg}$ of $4.3 \%$ per $\mathrm{cm}\left[\left(10^{0.0181}\right.\right.$. 1) $\times 100=4.3 \%$ ]. Because fish length was centered at $45 \mathrm{~cm}$ and latitude was centered at $45^{\circ}$, with year measured as years since 1980 , the intercept of -0.5277 corresponds to a $\mathrm{Hg}$ concentration of $0.30 \mu \mathrm{g} / \mathrm{g} \mathrm{Hg}\left(10^{-0.5277}\right)$ for a $45 \mathrm{~cm}$ fish from a lake at $45^{\circ}$ north latitude caught in the summer of 1980. Seasonal effects were measured as deviations from summer values, with fish caught in the spring being $12.8 \%\left[\left(10^{0.0597}-1\right) \times 100\right]$ higher in $\mathrm{Hg}$ concentration than those caught in the summer, and fish caught in the fall being $-1.5 \%\left[\left(10^{-0.0064}-1\right) \times 100\right]$ lower than summercaught fish. Hg increased with latitude, but this relationship
Table 1 Descriptive statistics of walleye (skin-on fillets) records included in mercury trend analysis (WIDNR 19822005)

\begin{tabular}{lcccccc}
\hline Variable & $n$ & Mean & SD & C.V. & Minimum & Maximum \\
\hline Fish length $(\mathrm{cm})$ & 3,024 & 45.0 & 8.5 & 19 & 25.4 & 76.7 \\
Fish weight $(\mathrm{kg})$ & 2,986 & 0.94 & 0.64 & 68 & 0.1 & 5.46 \\
Age (year) & 160 & 5.5 & 2.1 & 39 & 2 & 12 \\
Total mercury concentration $(\mu \mathrm{g} / \mathrm{g})$ & 3,024 & 0.474 & 0.326 & 69 & 0.030 & 3.1 \\
\hline
\end{tabular}


Table 2 Descriptive statistics of study lakes with selected mercury records

\begin{tabular}{|c|c|c|c|c|c|c|}
\hline Variable & $n$ & Mean & SD & C.V & Minimum & Maximum \\
\hline Max depth (meters) & 421 & 11.8 & 7.6 & 64 & 1.8 & 72.0 \\
\hline Drainage area (sq miles) & 189 & 14 & 46 & 337 & 1 & 491 \\
\hline Watershed area (sq miles) & 189 & 75 & 319 & 426 & 1 & 3,929 \\
\hline Waterbody size (acres) & 421 & 1,045 & 6,818 & 652 & 17 & 137,708 \\
\hline Wetland adjoin area (acres) & 421 & 541 & 3,932 & 727 & 0 & 78,060 \\
\hline Wetland-Lk area ratio & 421 & 0.91 & 5.39 & 591 & 0 & 87.89 \\
\hline pH (geo. mean, standard units) & 137 & 7.9 & 0.6 & 8 & 5.7 & 9.5 \\
\hline Alkalinity (geo. mean, mg/l total $\mathrm{CaCO}_{3}$ ) & 204 & 63.7 & 54.4 & 85 & 2.8 & 213 \\
\hline Color (geo. mean, standard units) & 207 & 27 & 28 & 105 & 5 & 150 \\
\hline Latitude (decimal degrees) & 421 & 45.5196 & 0.8286 & 2 & 42.5916 & 46.7951 \\
\hline Longitude (decimal degrees) & 421 & -90.0611 & 1.1787 & 1 & -92.711 & -87.1542 \\
\hline
\end{tabular}

Table 3 Descriptive statistics of lake means of walleye (skin-on fillet) records included in this study

\begin{tabular}{|c|c|c|c|c|c|c|}
\hline Variable & $n$ & Mean & SD & C.V. & Minimum & Maximum \\
\hline Lake mean $\mathrm{Hg}$ concentration $(\mu \mathrm{g} / \mathrm{g})$ & 421 & 0.483 & 0.306 & 63 & 0.063 & 2.2 \\
\hline Lake mean fish length $(\mathrm{cm})$ & 421 & 46.00 & 5.89 & 13 & 30.73 & 69.34 \\
\hline Lake mean year sampled & 421 & 1990.5 & 4.8 & 0.2 & 1983.7 & 2004.0 \\
\hline Lake mean number of years sampled & 421 & 1.5 & 0.9 & 57 & 1.0 & 7.0 \\
\hline Lake mean number of mercury results & 421 & 7 & 6 & 80 & 1 & 36 \\
\hline
\end{tabular}

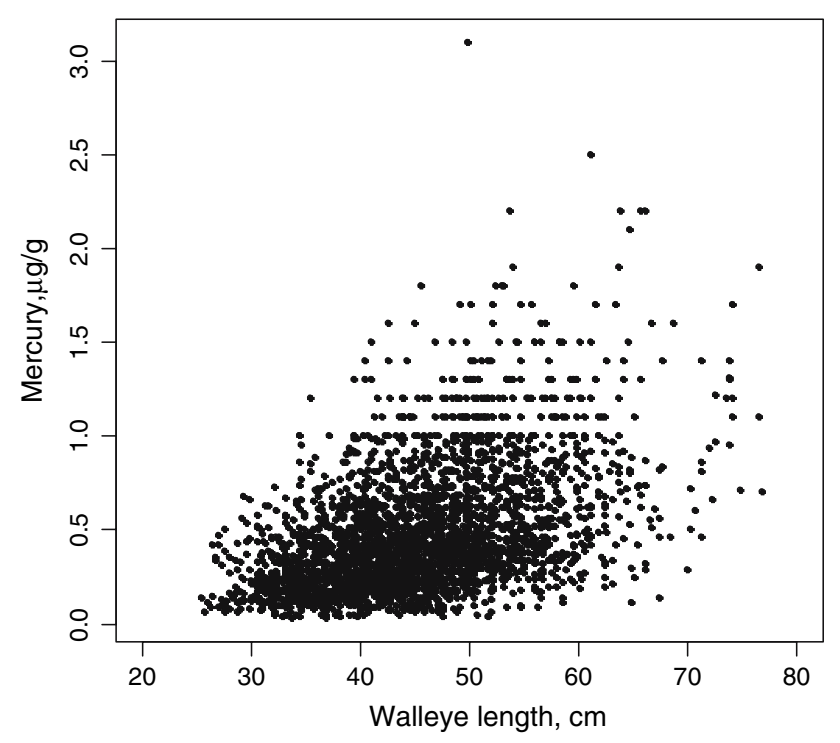

Fig. 1 Observed total $\mathrm{Hg}$ concentration $(\mu \mathrm{g} / \mathrm{g})$ for 3,024 walleye skin-on fillet samples from 421 Wisconsin lakes

varied among years, as indicated by the interaction between latitude and years (Fig. 3). The rate of increase in $\mathrm{Hg}$ with respect to latitude was greater early in the sampling period than during recent years. Equivalently, $\mathrm{Hg}$ decreased in northern Wisconsin lakes during the sampling period, while $\mathrm{Hg}$ increased in southern lakes. Because of the exponential increase of $\mathrm{Hg}$ with fish length, these relationships appear stronger for larger fish (Fig. 3). We confirmed these relationships by estimating time trends separately for southern, central, and northern Wisconsin lakes - trends in $\mathrm{Hg}$ concentrations $(\mu \mathrm{g} / \mathrm{g})$ averaged $+0.8 \%$ per year (linear trend $=0.0034, \mathrm{SE}=0.0037$ ) for southern lakes, were approximately zero (linear trend $=-0.0002$, $\mathrm{SE}=0.0019)$ for central lakes, and averaged $-0.5 \%$ per year (linear trend $=-0.002, \mathrm{SE}=0.0028$ ) for northern lakes.

Models including lake morphometry and watershed variables

Adding log of lake area or log of adjoining wetland area to Model 1 improved the fit; in particular, the model with log of lake area fit far better than any other model (Model 11, Table 5). Log of $\mathrm{Hg}$ concentration decreased as the $\log$ of lake area increased and the variance among lake intercepts was reduced from its value in the simpler model because this model accounted for more of the lake differences (Table 5). Because both $\mathrm{Hg}$ concentration and lake area were log-transformed, the slope of -0.1487 indicates that if lake size is doubled, $\mathrm{Hg}$ concentration decreases by $9.8 \%$.

Models including lake alkalinity and gender of fish

Because alkalinity was not available for all lakes and gender not known for all fish, we used subsets of the data to 
Table 4 Models fit by maximum likelihood $(M L)$, listed in order with best fit first

\begin{tabular}{llc}
\hline Model number & Fixed effects & $\Delta$ AIC \\
\hline Model 1 & L Y S lat lat*Y & 0 \\
Model 2 & L Y S lat & 4.6 \\
Model 3 & L Y S & 21.3 \\
Model 4 & L Y lat lat*Y & 25.6 \\
Model 5 & L Y lat & 31.4 \\
Model 6 & L Y & 53.2 \\
Model 7 & L S lat & 110.7 \\
Model 8 & L S & 125.5 \\
Model 9 & L lat & 177.7 \\
Model 10 & L & 198.4 \\
\hline
\end{tabular}

$\triangle \mathrm{AIC}$ is the difference in AIC from best-fitting model (model with minimum AIC). All models include an intercept. Abbreviations used for factors in models are: $L$ fish length, lat latitude, $S$ season, $Y$ year sampled, lat* $Y$ latitude by year interaction

Table 5 Models based on best model from Table 4, but also including lake morphometry and watershed data

\begin{tabular}{llc}
\hline Model number & Fixed effects & $\Delta$ AIC \\
\hline Model 11 & L Y S lat lat*Y logArea & 0 \\
Model 12 & L Y S lat lat*Y logWetland & 38.1 \\
Model 13 & L Y S lat lat*Y & 42.0 \\
Model 14 & L Y S lat lat*Y ratio & 43.6 \\
Model 15 & L Y S lat lat*Y depth & 43.8 \\
\hline
\end{tabular}

Other variables included are: $\log$ Area $\log$ of waterbody area, $\log$ Wetland log of adjoining wetland area, depth waterbody maximum depth, ratio ratio of adjoining wetland area to waterbody area

examine models including these predictor variables. Gender was known for 1,953 fish from 318 lakes. Alkalinity was available for 204 lakes, with 1,642 fish sampled. For each of these two subsets, we first fit the best model identified for all lakes (Model 11 with predictor variables fish length, season collected, year collected, lake latitude, year by latitude interaction, and log of lake area). Adding gender as a predictor variable significantly improved the fit of the model (AIC decreased by 68.8). Walleye $\mathrm{Hg}$ was $14.7 \%$ lower $\left[\left(10^{-0.069}-1\right) \times 100\right]$ for females than for males of equal size. Adding log of alkalinity as a predictor variable significantly improved the fit of the model (AIC decreased by 23.8). Walleye $\mathrm{Hg}$ decreased by $14.4 \%$ as alkalinity doubled. The model including fish length, season collected, year collected, latitude, the latitude by year interaction, $\log$ of lake area, and the $\log$ of alkalinity fit approximately as well as a slightly simpler model that did not include latitude or the latitude by year interaction, but included instead the interaction between year and log of alkalinity (AIC for the latter model was 0.5 smaller). This suggests that the geographical pattern in walleye $\mathrm{Hg}$ time trends may be related to water chemistry differences between northern and southern lakes. In fact, in our data set latitude and alkalinity were strongly negatively correlated $(r=-0.82, P<0.001)$.

\section{Discussion}

Our analyses suggest that temporal trends in walleye $\mathrm{Hg}$ concentrations vary latitudinally within WI, with northern lakes exhibiting slight average decreases $(-0.5 \%$ per year $)$ and southern lakes modest average increases in $\mathrm{Hg}$ concentration $(0.8 \%$ per year) over the time period from 1982 to 2005. The random effects associated with time trends indicate that individual lakes may deviate from these population averages. For the subset of lakes on which alkalinity was measured, we found that models in which time trend differences were related to alkalinity or to latitude fit equally well. Because northern Wisconsin lakes are generally lower in alkalinity and southern lakes generally higher, it is difficult to separate the effects of alkalinity and latitude in our observational study. Furthermore, other factors, including lake chemistry, atmospheric deposition, lake productivity, and fish growth rates, are also associated with latitude and alkalinity, so that several explanations for patterns in time trends are possible. Regional and local differences in walleye $\mathrm{Hg}$ trends are likely because of the complex interplay between atmospheric deposition of $\mathrm{Hg}$, lake alkalinity and $\mathrm{pH}$, and factors that affect microbial community composition and activity, such as the nutrient loading from runoff, or climate change (Watras et al. 2006).

Our finding that walleye $\mathrm{Hg}$ concentrations decreased in northern Wisconsin is consistent with other studies. $\mathrm{Hg}$ concentrations in northern pike and walleye from Minnesota declined by an average of $11 \%$ between 1990 and 2000, or $\sim 1 \%$ per year (MPCA 2007). Madsen and Stern (2007) found walleyes (skin-on and skin-off fillets) from northern Wisconsin decreased 0.6\%/year over 1982-2005 using hierarchical Bayesian methods. In a study of common loons in northern Wisconsin, Fevold et al. (2003) estimated that adult loon blood $\mathrm{Hg}$ levels decreased by $4.2 \%$ per year, while loon chick blood $\mathrm{Hg}$ decreased by $4.9 \%$ per year. Engstrom and Swain (1997) found sediment cores showed evidence of recent declines in $\mathrm{Hg}$ deposition to lakes in northeastern Minnesota after reaching a peak in the 1960s-1970s. Hrabik and Watras (2002) attributed the decreases in yellow perch $\mathrm{Hg}$ concentration to decreases in atmospheric deposition of $\mathrm{H}_{2} \mathrm{SO}_{4}$ and $\mathrm{Hg}$ that occurred in northern Wisconsin after 1988 (Watras et al. 2000). Sulfate deposition and frequency of acidic precipitation has decreased throughout the Midwest (Lehman et al. 2007). In the poorly buffered lakes typical of northern Wisconsin, 


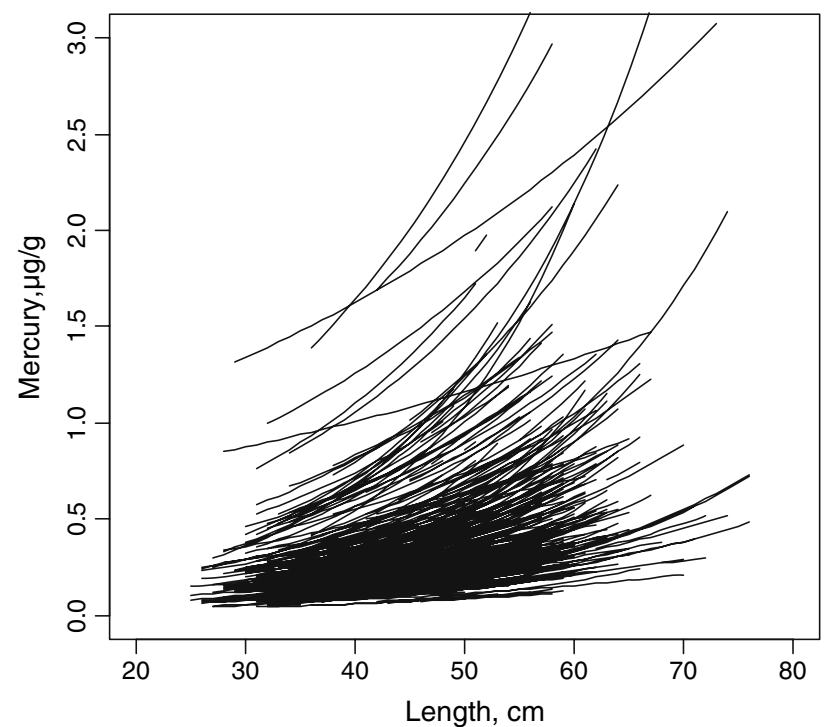

Fig. 2 Predicted total $\mathrm{Hg}$ for the year 1995 from best fitting model (Model 1) without variables on lake morphometry or watershed data. Each line represents predictions for fish from one lake, over the size range of fish observed for that lake lakes. Also, the well buffered lakes of southern Wisconsin are much less likely to show changes in lake chemistry due to regional decrease in sulfate deposition than are the poorly buffered lakes of northern Wisconsin. However, our finding of increased walleye $\mathrm{Hg}$ in southern lakes warrants further study. There are fewer lakes in southern Wisconsin and our data set includes fewer fish from southern lakes (573 fish from 62 lakes south of $45^{\circ}$ latitude).

Researchers have long recognized that mean walleye $\mathrm{Hg}$ concentrations vary greatly among lakes, and have sought to find factors to explain this (e.g., Wiener et al. 1990; Lathrop et al. 1991; Wren et al. 1991). In our analyses, lake differences were expressed as differences in both the intercept and slope of the $\log _{10}(\mathrm{Hg})$-walleye length relationship. Although our study was not directed primarily at examining factors that account for lake differences in walleye $\mathrm{Hg}$ concentration, we found that lake latitude, area, and alkalinity explained some of the differences in intercepts among lakes, but that none accounted for slope differences. Neither lake latitude nor alkalinity are likely to be direct causes of differences in walleye $\mathrm{Hg}$ concentrations,

Table 6 Parameter estimates from best models (model 1 and 11) fit by restricted maximum likelihood (REML)

\begin{tabular}{|c|c|c|c|c|}
\hline Parameter & Model 1 estimate & SE & Model 11 estimate & SE \\
\hline Intercept & -0.5277 & 0.0244 & -0.1426 & 0.0618 \\
\hline Fish length & 0.0181 & 0.0005 & 0.0180 & 0.0005 \\
\hline Latitude & 0.1072 & 0.0227 & 0.0950 & 0.0220 \\
\hline Year & 0.0008 & 0.0016 & 0.0010 & 0.0015 \\
\hline Latitude*year & -0.0038 & 0.0015 & -0.0038 & 0.0014 \\
\hline Log waterbody area & - & - & -0.1487 & 0.0220 \\
\hline Spring-summer & 0.0597 & 0.0136 & 0.0620 & 0.0135 \\
\hline Fall-summer & -0.0064 & 0.0204 & -0.0051 & 0.0202 \\
\hline \multicolumn{5}{|c|}{ Variance components (expressed as standard deviations) } \\
\hline Intercept & 0.2693 & & 0.2574 & \\
\hline Fish length & 0.0063 & & 0.0063 & \\
\hline Year & 0.0130 & & 0.0127 & \\
\hline Within lake (residual) & 0.1339 & & 0.1340 & \\
\hline
\end{tabular}

SE standard errors

decreases in sulfate deposition may change lake chemistry in ways that reduce the efficiency of $\mathrm{Hg}$ methylation (MPCA 2006; Munthe et al. 2007).

Our analyses also suggest slight increases in walleye $\mathrm{Hg}$ concentrations in southern Wisconsin. Hg deposition tends to be greater in southeastern Wisconsin and these lakes may be receiving more $\mathrm{Hg}$ than northern lakes. However, we do not have temporal trend estimates for $\mathrm{Hg}$ deposition to most Wisconsin lakes (WIDNR 1999). Engstrom and Swain (1997) found no evidence of decreased Hg deposition in sediment core samples from west-central Minnesota but both are probably correlated with other causative factors. We included latitude in our models, not only to account for spatial sampling patterns in our observational study, but also because it is generally associated with gradients in $\mathrm{pH}$ and alkalinity, lake productivity, and fish growth, all factors suspected or demonstrated to be important to $\mathrm{Hg}$ bioaccumulation. In Wisconsin, $\mathrm{pH}$ and alkalinity, lake productivity, and fish growth rates all tend to decrease with increasing latitude (Lillie and Mason 1983; Nate 2004). Alkalinity and pH themselves are probably correlated with causative factors such as the 

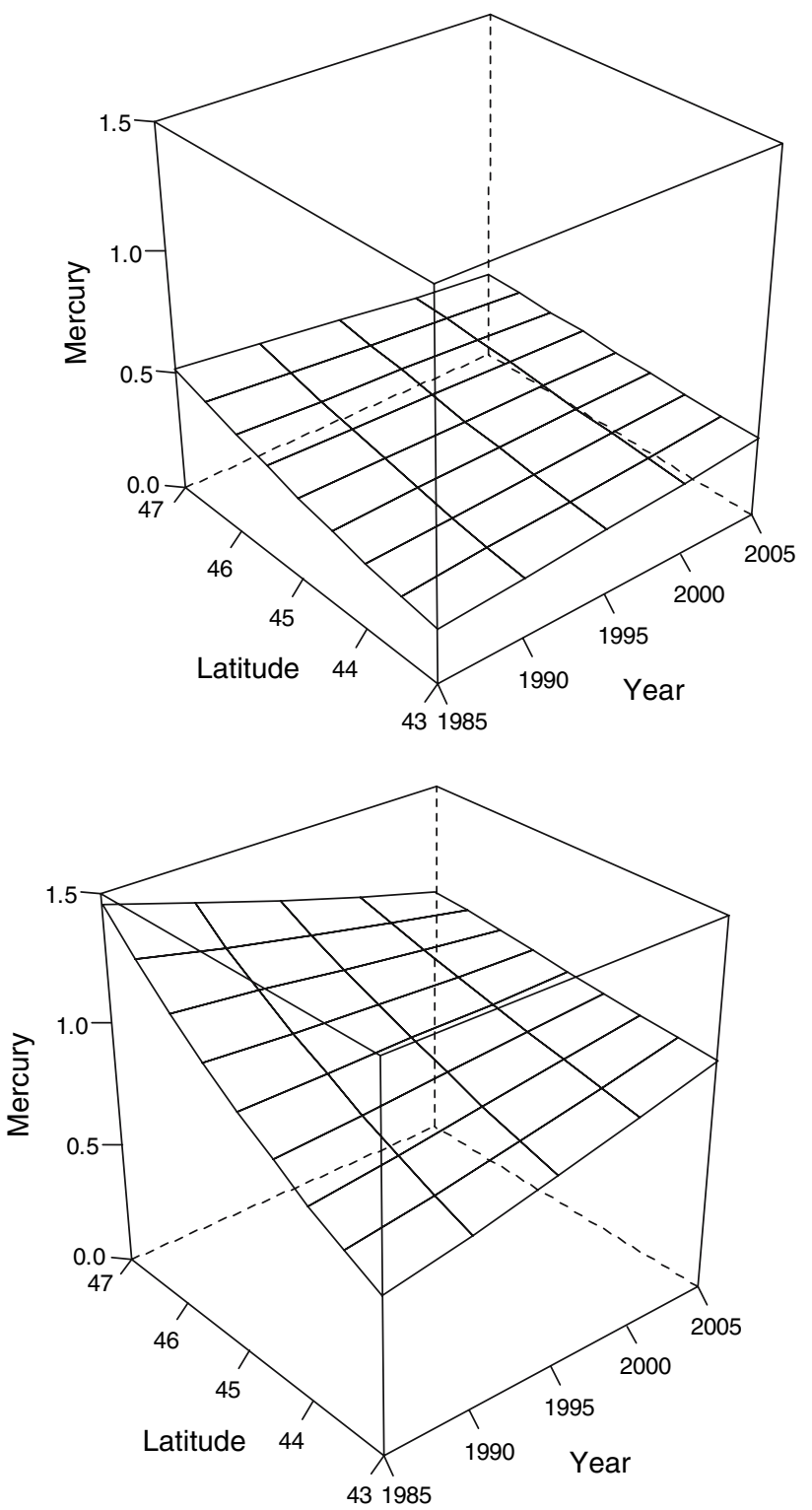

Fig. 3 Predicted mercury $(\mu \mathrm{g} / \mathrm{g})$ in skin-on fillets of a $45 \mathrm{~cm}$ walleye (top panel) and a $70 \mathrm{~cm}$ walleye (bottom panel) by year sampled and lake latitude (decimal degrees)

activity of sulfate-reducing bacteria leading to increased rates of methyl $\mathrm{Hg}$ production (Watras et al. 2006). Increased lake productivity and warmer water temperatures in southern Wisconsin lead to faster fish growth rates, which Simoneau et al. (2005) have found to be associated with lower $\mathrm{Hg}$ concentrations in fish of the same length. High lake productivity is also associated with higher densities of phytoplankton and zooplankton and reduced rates of $\mathrm{Hg}$ trophic transfer (Chen and Folt 2005). Both Bodaly et al. (1993) and Greenfield et al. (2001) found that lake size and fish $\mathrm{Hg}$ are negatively related, just as we did. They suggested that this was due either to higher temperatures in smaller lakes, leading to higher rates of methylation, or to proportional increases in organic matter input in smaller lakes, which tends to reduce oxygen levels and increase rates of methylation by sulfate-reducing bacteria.

Differences in walleye $\mathrm{Hg}$ among fish within lakes were related to fish length, gender, and the season of collection. The increase in $\mathrm{Hg}$ concentration with fish length is well known (MacCrimmon et al. 1983; Wiener et al. 1990; Wiener and Spry 1996) and has been modeled using mechanistic models that account for bioenergetic and physiological parameters (Trudel and Rasmussen 2001). The higher concentration of $\mathrm{Hg}$ in males than females at the same length is probably due to the higher growth rate of females; males take longer to reach the same size, and consume more $\mathrm{Hg}$ during that time (Henderson et al. 2003). We found that for walleye of the same length, $\mathrm{Hg}$ concentrations were highest in fish collected in spring; this was also the season in which most of our samples were collected. Post et al. (1996) suggested that seasonal changes in $\mathrm{Hg}$ concentrations in fish are caused by seasonally varying diet and growth efficiency, although they found highest $\mathrm{Hg}$ concentrations in late summer for age- 0 yellow perch. Fish $\mathrm{Hg}$ may also reflect seasonally varying methylmercury water column concentrations (Monson and Brezonik 1998; Eckley and Hintelmann 2006).

Our findings suggest that $\mathrm{Hg}$ in walleye from Wisconsin lakes changed in the range of -0.5 to $0.8 \%$ per year depending on geographical position in the state during the period of 1982-2005. These trends may reflect geographically differing temporal trends in the amount of $\mathrm{Hg}$ deposited to Wisconsin lakes. However, long-term changes in other factors, such as water chemistry, fish growth rates, and lake levels, known to impact $\mathrm{Hg}$ bioavailability and accumulation may also be important. These findings should be re-evaluated in future years.

Acknowledgments Special thanks to Drs. Michael W. Meyer and Nancy A. Nate for reviewing early drafts of this manuscript. Assistance of staff at the Wisconsin State Laboratory of Hygiene is appreciated. The Wisconsin Department of Natural Resources generated the data summarized in this report through efforts over many years supported by different sources of funding including state and federal programs. Collection of 2003-2005 samples was partially funded by the FOCUS on ENERGY Program administered by the Department of Administration. Data compilation and analysis was funded in part by the FOCUS on ENERGY Program.

\section{References}

Bodaly RA, Rudd JWM, Fudge RJP, Kelly CA (1993) Mercury concentrations in fish related to the size of remote Canadian Shield Lakes. Can J Fish Aquat Sci 50:980-987

Burnham KP, Anderson DR (1998) Model selection and inference: a practical information theoretic approach. Springer-Verlag, New York, USA 
Chen CY, Folt CL (2005) High plankton densities reduce mercury biomagnification. Environ Sci Technol 39:115-121

Colby PJ, Nepszy SJ (1981) Variation among stocks of walleye (Stizostedion vitreum vitreum): management implications. Can J Fish Aquat Sci 38:1814-1831

Driscoll CT, Blette V, Yan C, Schoefield CL, Munson R, Holsapple J (1995) The role of dissolved organic carbon in the chemistry and bioavailability of mercury in remote Adirondack lakes. Water Air Soil Pollut 80:499-508

Eckley CS, Hintelmann H (2006) Determination of mercury methylation potentials in the water column of lakes across Canada. Sci Total Environ 368(1):111-125

Engstrom DR, Swain EB (1997) Recent declines in atmospheric mercury deposition in the upper midwest. Environ Sci Technol 31(4):960-967

Fevold BM, Meyer MW, Rasmussen PW, Temple SA (2003) Bioaccumulation patterns and temporal trends of mercury exposure in Wisconsin Common loons. Ecotoxicology 12:83-93

Glass GE, Sorensen JA (1999) Six-year trend (1990-1995) of wet mercury deposition in the Upper Midwest, USA. Environ Sci Technol 33:3303-3312

Greenfield BK, Hrabik TT, Harvey CJ, Carpenter SR (2001) Predicting mercury levels in yellow perch: use of water chemistry, trophic ecology, and spatial traits. Can J Fish Aquat Sci 58(7):1419-1429

Henderson BA, Collins N, Morgan GE, Vaillancourt A (2003) Sexual size dimorphism of walleye (Stizostedion vitreum vitreum). Can J Fish Aquat Sci 60(11):1345-1352

Hrabik TR, Watras CJ (2002) Recent declines in mercury concentrations in a freshwater fishery: isolating the effects of deacidification and decreased atmospheric mercury deposition in Little Rock Lake. Sci Total Environ 297:229-237

Johnson DH (2002) The importance of replication in wildlife research. J Wildl Manage 66:919-932

Lathrop RC, Noonan KC, Guenther PM, Brasino TL, Rasmussen PW (1989) Mercury levels in walleyes from Wisconsin lakes of different water and sediment chemistry characteristics. Technical Bulletin No. 163. Department of Natural Resources. Madison, WI

Lathrop RC, Rasmussen PW, Knauer DR (1991) Mercury concentrations in walleyes from Wisconsin (USA) lakes. Water Air Soil Pollut 56:295-307

Lehmann CMB, Bowersox VC, Larson RS, Larson SM (2007) Monitoring long-term trends in sulfate and ammonium in US precipitation: results from the national atmospheric deposition program/national trends network. Water, Air, Soil Pollution: Focus 7(1-3):59-66

Lillie R, Mason J (1983) Limnological characteristics of wisconsin lakes. Technical Bulletin No. 138. Department of Natural Resources. Madison, WI

Littell RC, Milliken GA, Stroup WW, Wolfinger RD (1996) SAS System for Mixed Models. SAS Institute, Inc., Cary, NC, USA

MacCrimmon HR, Wren CD, Gots BL (1983) Mercury uptake by lake trout, Salvelinus namaycush, relative to age, growth, and diet in Tadenac Lake with comparative data from other Precambrian shield lakes. Can J Fish Aquat Sci 40(2):114-120

Madsen ER, Stern HS (2007) Time trends of methylmercury in walleye in northern Wisconsin: a hierarchical Bayesian analysis. Environ Sci Technol 41(13):4568-4573

Monson BA, Brezonik PL (1998) Seasonal patterns of mercury species in water and plankton from softwater lakes in Northeastern Minnesota. Biogeochemistry 40(2-3):147-162

MPCA (Minnesota Pollution Control Agency) (2007) Minnesota statewide mercury total maximum daily load, Final March 27, 2007. (http://www.pca.state.mn.us/publications/wqiw4-01b.pdf)
Munthe RA, Bodaly RA, Branfireun BA, Driscoll CT, Gilmour CC, Harris R, Horvat M, Lucotte M, Malm O (2007) Recovery of mercury-contaminated fisheries. Ambio 36(1):33-44

Nate NA (2004) Variability in fish growth rates in relation to physical and landscape characteristics of Michigan and Wisconsin inland lakes. Doctoral dissertation. Michigan State University, Lansing, MI, USA

Post JR, Vandenbos R, McQueen DJ (1996) Uptake rates of foodchain and waterborne mercury by fish: field measurements, a mechanistic model, and an assessment of uncertainties. Can J Fish Aquat Sci 53(2):395-407

Quist MC, Guy CS, Schultz RD, Stephan JL (2003) Latitudinal comparisons of walleye growth in north America and factors influencing growth of walleyes in Kansas reservoirs. North Am J Fish Manage 23:677-792

Rudd JWM (1995) Sources of methyl mercury to freshwater ecosystems: a review. Water Air Soil Pollut 80:697-713

Schuster PF, Krabbenhoft DP, Naftz DL, Cecil LD, Olson ML, Dewild JF, Susong DD, Green JR, Abbott ML (2002) Atmospheric mercury deposition during the last 270 years: a glacial ice core record of natural and anthrophogenic sources. Environ Sci Technol 36:2303-2310

Simoneau M, Lucotte M, Garceau S, Laliberté D (2005) Fish growth rates modulate mercury concentrations in walleye (Sander vitreus) from eastern Canadian lakes. Environ Res 98:73-82

Slemr F, Brunke E, Ebinghaus R, Temme C, Munthe J, Wangberg I, Schroeder W, Steffen A, Berg T (2003) Worldwide trend of atmospheric mercury since 1977. Geophys Res Lett 30(10):1516

Somers KM, Jackson DA (1993) Adjusting mercury concentration for fish-size covariation: a multivariate alternative to bivariate regression. Can J Fish Aquat Sci 50(11):2388-2396

St. Louis VL, Rudd JWM, Kelly CA, Beaty KG, Flett RJ, Roulet NT (1996) Production and loss of methylmercury and loss of total mercury from boreal forest catchments containing different types of wetlands. Environ Sci Technol 30:2719-2729

Sullivan JR, Delfino JJ (1982) The determination of mercury in fish. J Environ Sci Health A17(2):265-275

Suns K, Hitchin G (1990) Interrelationships between mercury levels in yearling yellow perch, fish condition, and water quality. Water, Air, Soil, Pollut 650:255-265

Trudel M, Rasmussen JB (2001) Predicting mercury concentration in fish using mass balance models. Ecol Applicat 11(2):517-529

Verbeke G, Molenberghs G (2000) Linear mixed models for longitudinal data. Springer, New York, USA

Watras CJ, Back RC, Halvorsen S, Hudson RJM, Morrison KA, Wente SP (1998) Bioaccumulation of mercury in pelagic freshwater food webs. Sci Total Environ 219:183-208

Watras CJ, Morrison KA, Hudson RJM, Frost TM, Kratz TK (2000) Decreasing mercury in northern Wisconsin: temporal patterns in bulk precipitation and a precipitation-dominated lake. Environ Sci Technol 34:4051-4057

Watras CJ, Morrison KA, Regnell O, Kratz TK (2006) The methylmercury cycle in Little Rock Lake during experimental acidification and recovery. Limnol Oceanogr 51:257-270

Wiener JG (1983) Comparative analyses of fish populations in naturally acidic and circumneutral lakes in northern Wisconsin. US Fish and Wildlife Service Report FWS/OBS-80/40.16

Wiener JG, Bodaly RA, Brown SS, Lucotte M, Newman MC, Porcella DB, Reash RJ, Swain EB (2007) Monitoring and evaluating trends in methylmercury accumulation in aquatic biota. In: Harris RC, Krabbenhoft DP, Mason RP, Murray MW, Reash RJ, Saltman T (eds) Ecosystem responses to mercury contamination: indicators of change, Chap 4. Taylor and Francis, Boca Raton, FL, USA, pp 87-122

Wiener JG, Knights BC, Sandheinrich MB, Jeremiason JD, Brigham ME, Engstrom DR, Woodruff LG, Cannon WF, 
Balogh SJ (2006) Mercury in soils, lakes, and fish in Voyageurs National Park (Minnesota): importance of atmospheric deposition and ecosystem factors. Environ Sci Technol 40(20):6261-6268

Wiener JG, Martini RE, Sheffy TB, Glass GE (1990) Factors influencing mercury concentrations in walleyes in northern Wisconsin lakes. Trans Am Fish Soc 119:862-870

Wiener JG, Spry DJ (1996) Toxicological significance of mercury in freshwater fish. In: Beyer WN, Heinz GH, Redmon AW (eds) Environmental contaminants in wildlife: interpreting tissue concentrations. CRC, Boca Raton, FL, USA, pp 297-339
Wisconsin Department of Natural Resources (WIDNR) (1999) Wisconsin mercury deposition network summary Report, vol 2. PUB-AM-302-99. Madison, WI, USA

Wisconsin State Laboratory of Hygiene (September 2005) Quality assurance procedures and policies. Revision 4.0. Madison, WI, USA

Wren CD, Scheider WA, Wales DL, Muncaster BW, Gray IM (1991) Relation between mercury concentrations in walleye (Stizostedion vitreum vitreum) and northern pike (Esox lucius) in Ontario lakes and influence of environmental factors. Can J Fish Aquat Sci 48:132-139 